\title{
Effect of Composite Feed Additive on Fluctuations in Milk Production and Milk Composition in Lactating Murrah (Bubalus bubalis) Buffaloes
}

\author{
Kiran $^{1,2^{*}}$ and Avijit Dey ${ }^{2}$ \\ ${ }^{1}$ Animal Nutrition Division, ICAR-National Dairy Research Institute, Karnal, Haryana, India \\ ${ }^{2}$ ANFT Division, ICAR-Central Research Institute for Research on Buffaloes, Hisar, \\ Haryana, India \\ *Corresponding author
}

\begin{tabular}{|c|}
\hline Keywords \\
\hline $\begin{array}{l}\text { Composite feed } \\
\text { additive, Milk yield, } \\
\text { Murrah buffaloes }\end{array}$ \\
\hline Article Info \\
\hline $\begin{array}{l}\text { Accepted: } \\
\text { 04 July } 2018 \\
\text { Available Online: } \\
10 \text { August } 2018\end{array}$ \\
\hline
\end{tabular}

\section{A B S T R A C T}

The study was conducted to examine the effect of composite feed additive on fluctuations in weekly milk production and milk composition in lactating buffaloes. The experiment was carried out in buffalo farm ICAR-CIRB Hisar. Murrah lactating buffaloes $(n=18)$ (Bubalus bubalis) (avg. milk yield 10.83 $\pm 1.56 \mathrm{~kg}$ ) and (avg. live weight, $507.24 \pm 44.18$ $\mathrm{kg}$; parity, 2-5) at early stage (30 days) of lactation were selected and divided into two groups of 8 animals each using a completely randomized block design. They were allocated into two dietary groups, control and treatment containing basal feed without or with composite feed additives, respectively. Composite feed additive (CFA) was fed @ $2.5 \%$ of total dry matter intake in the CFA fed group along with concentrate mixture. Initial milk yield of control and treatment group was $10.78 \pm 1.86$ and $10.87 \pm 1.31$ respectively which were comparable between the both groups $(\mathrm{p}>0.05)$. The initial milk protein $\%$, milk fat $\%$, lactose $\%$ and SNF\% were $4.26 \pm 0.32$ and $4.25 \pm 0.25,6.67 \pm 0.73$ and $6.86 \pm 0.73,4.51 \pm 0.23$ and $4.52 \pm 0.22,9.31 \pm 0.31$ and $9.32 \pm 0.16$ in control and treatment group. Initial milk yield $\left(\mathrm{kg} \mathrm{d}^{-1}\right)$ of both the groups were similar $(\mathrm{p}>0.05)$. Although there are differences in milk yield $\left(\mathrm{kg} \mathrm{d}^{-1}\right)$ throughout the study, it was comparable $(\mathrm{p}>0.05)$ statistically between control and treatment groups. The weekly milk composition in term of fat (\%), solid-not-fat (SNF \%), protein (\%) and lactose (\%) showed no apparent variations $(p>0.05)$ between the groups.

\section{Introduction}

Milk production in lactating animals udders is a complex and dynamic physiological process. Milk production and milk compositions varies with age of animal, days in milk, parity, basal diet fed along with concentrate and physiological status of the animal, hence needed to be carefully studied. With increasing population, demand for animal products are also increasing hence it become necessary to increase milk production by utilizing limited resources of feed and fodder available. Researchers round the globe are working hard to develop different techniques and feed additives which can enhance animal milk production and provide balanced nutrients. Blanch et al., (2016) studied the effect of supplementation of commercial product, Next Enhance ${ }^{8} 300 \quad$ (NE300; 
cinnamaldehyde and garlic oil encapsulated product) on rumen fermentation and milk production of dairy cows and reported that multiparous cows on NE300 supplemented diet, produced more milk (additional $3 \mathrm{~kg} / \mathrm{d}$ ) than the unsupplemented control. Supplementation of cinnamaldehyde and condensed tannins from quebracho trees saponins from Yucca schidigera extract in cows had been reported to have no effect on milk production, milk fat and milk protein among dietary treatments (Benchaar et al., 2008). Hence a composite feed additive was developed by ICAR-CIRB, Hisar to study its effect in lactating Murrah buffaloes on milk production and milk composition.

\section{Materials and Methods}

\section{Animals and management}

Murrah buffaloes $(\mathrm{n}=18)$ were selected (avg. milk yield $10.83 \pm 1.56 \mathrm{~kg}$ ) and (avg. live weight, $507.24 \pm 44.18 \mathrm{~kg}$; parity, 2-5) at early stage (30 days) of lactation for the experiment and divided into two groups (CFA and CON). The experiment was conducted for three months. Farm grown green sorghum (about 25 $\mathrm{kg}$ ) was offered at 11:00 am every day, after ensuring complete consumption of concentrates. Wheat straw was offered ad libitum. Water was freely available to the buffaloes. The animals were housed in roofed, cement-floored stalls with individual feeding provision and adapted to their respective diets for a period of 15 days.

\section{Collection of samples}

Animals were milked twice a day by full hand milking technique and milk samples $(100 \mathrm{ml}$ each) were collected on the test days. During the study of three months feeding 220 individual milk samples were collected from 18 lactating buffaloes and analysed weekly. Total Milk yield of morning and evening from each animal was recorded using automatic weighing balance of capacity of $100 \mathrm{~kg}$. Samples were collected from milk weighing bucket after complete milking and through mixing and stored at $4{ }^{\circ} \mathrm{C}$ until processed and analysed on same day. Milk components like milk fat, milk protein, solid not fat (SNF) and lactose using pre-calibrated automatic ultrasonic milk analyzer (LACTOSCAN LA, 8900 Zagora).

\section{Statistical analysis}

Data obtained were subjected to analysis of variance (ANOVA) using SPSS 17.0 software and treatment means were ranked using Duncan's multiple range tests according to Snedecor and Cochran (1994). The data are expressed as mean $\pm \mathrm{SD}$ with significance level $\mathrm{p}<0.05$.

\section{Results and Discussion}

Initial milk yield in start of experiment were $10.78 \pm 1.86$ and $10.87 \pm 1.31$, that were comparable statistically $(\mathrm{p}>0.05)$ in control and treatment group. In the end it was found that milk yield in treatment group was $11.31 \pm$ 1.83 and in control group was $9.42 \pm 3.13$.

This shows that there was more milk production in treatment group $(1.89 \mathrm{~kg})$ than control group. Blanch et al., (2016) studied the effect of supplementation of commercial product, Next Enhance ${ }^{\circledR 300}$ (NE300; cinnamaldehyde and garlic oil encapsulated product) on rumen fermentation and milk production of dairy cows and reported that multiparous cows on NE300 supplemented diet, produced more milk (additional $3 \mathrm{~kg} / \mathrm{d}$ ) than the unsupplemented control. Figure 1 shows milk production in treatment and control group.

Milk protein $\%$, milk fat $\%$, lactose $\%$ and SNF\% were $4.26 \pm 0.32$ and $4.25 \pm 0.25$, 
$6.67 \pm 0.73$ and $6.86 \pm 0.73, \quad 4.51 \pm 0.23$ and $4.52 \pm 0.22,9.31 \pm 0.31$ and $9.32 \pm 0.16$ in control and treatment group and were comparable statistically $\quad(\mathrm{p}>0.05) \quad$ (Fig. 2). Depict variations in lactose and protein \% in lactating buffaloes.

Fig.1 Effect of composite feed additive on milk production in buffaloes

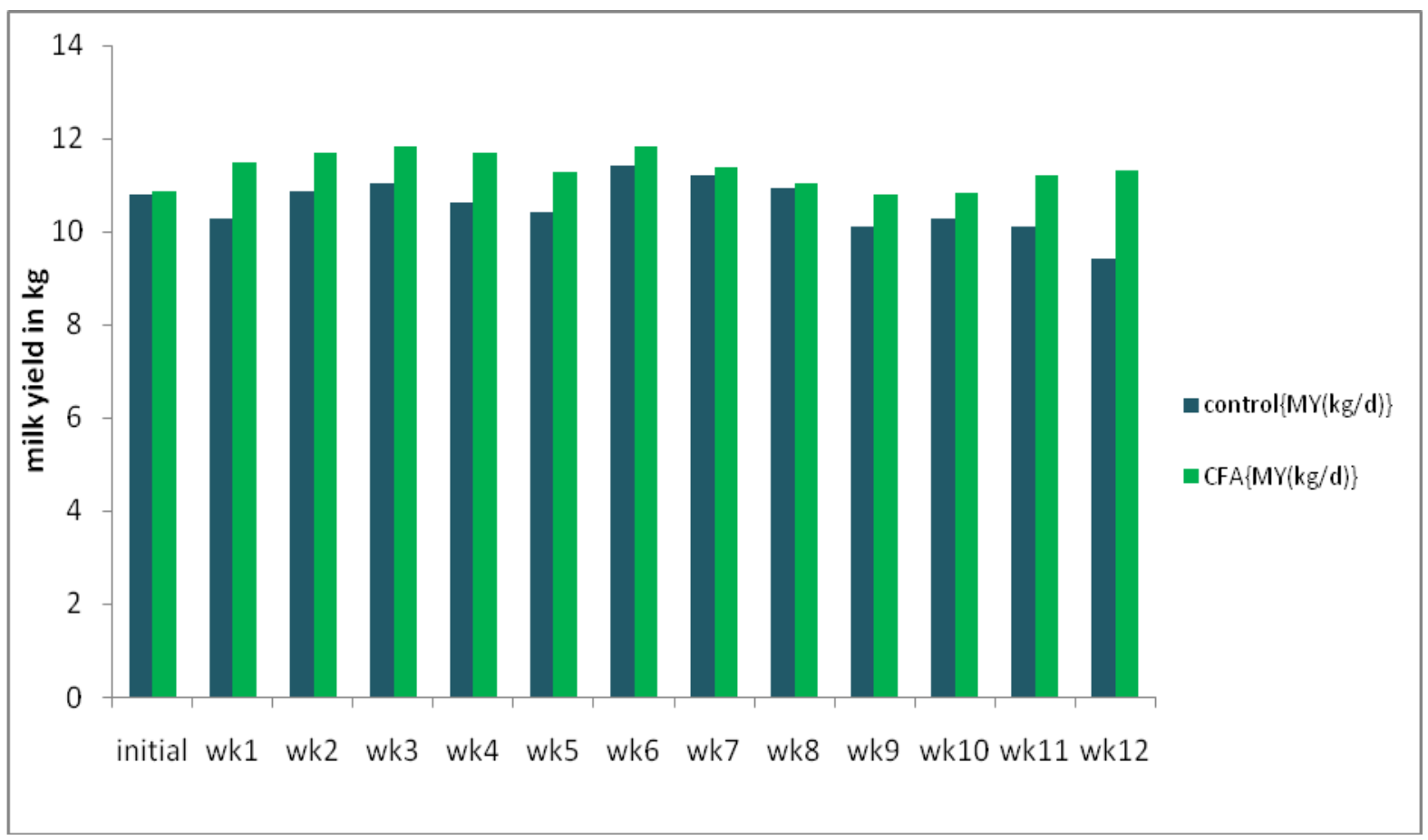

Fig.2 Effect of composite feed additive on milk lactose and protein \% in buffaloes

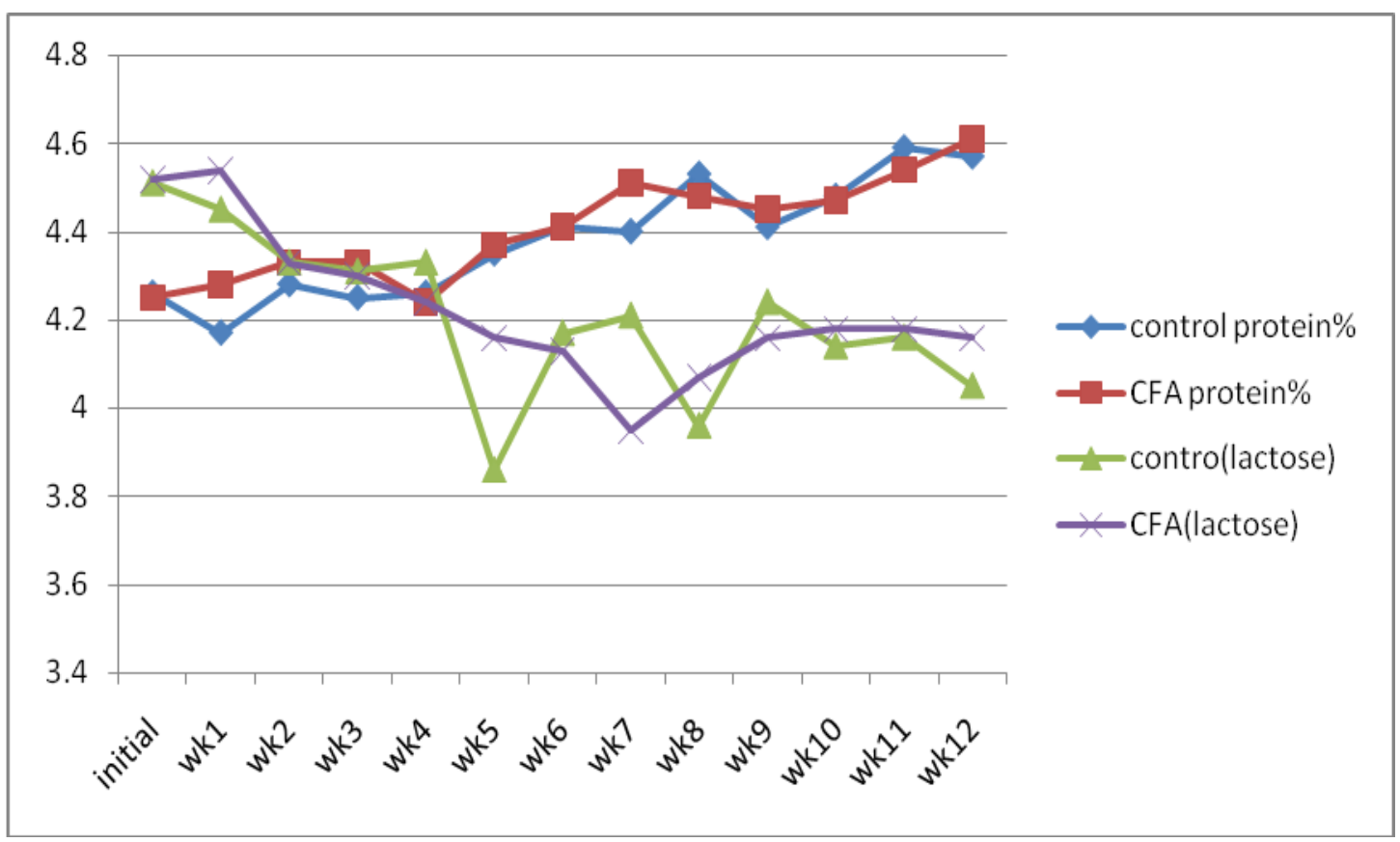


Fig.3 Effect of composite feed additive on fat $\%$ and SNF\% in milk of buffaloes

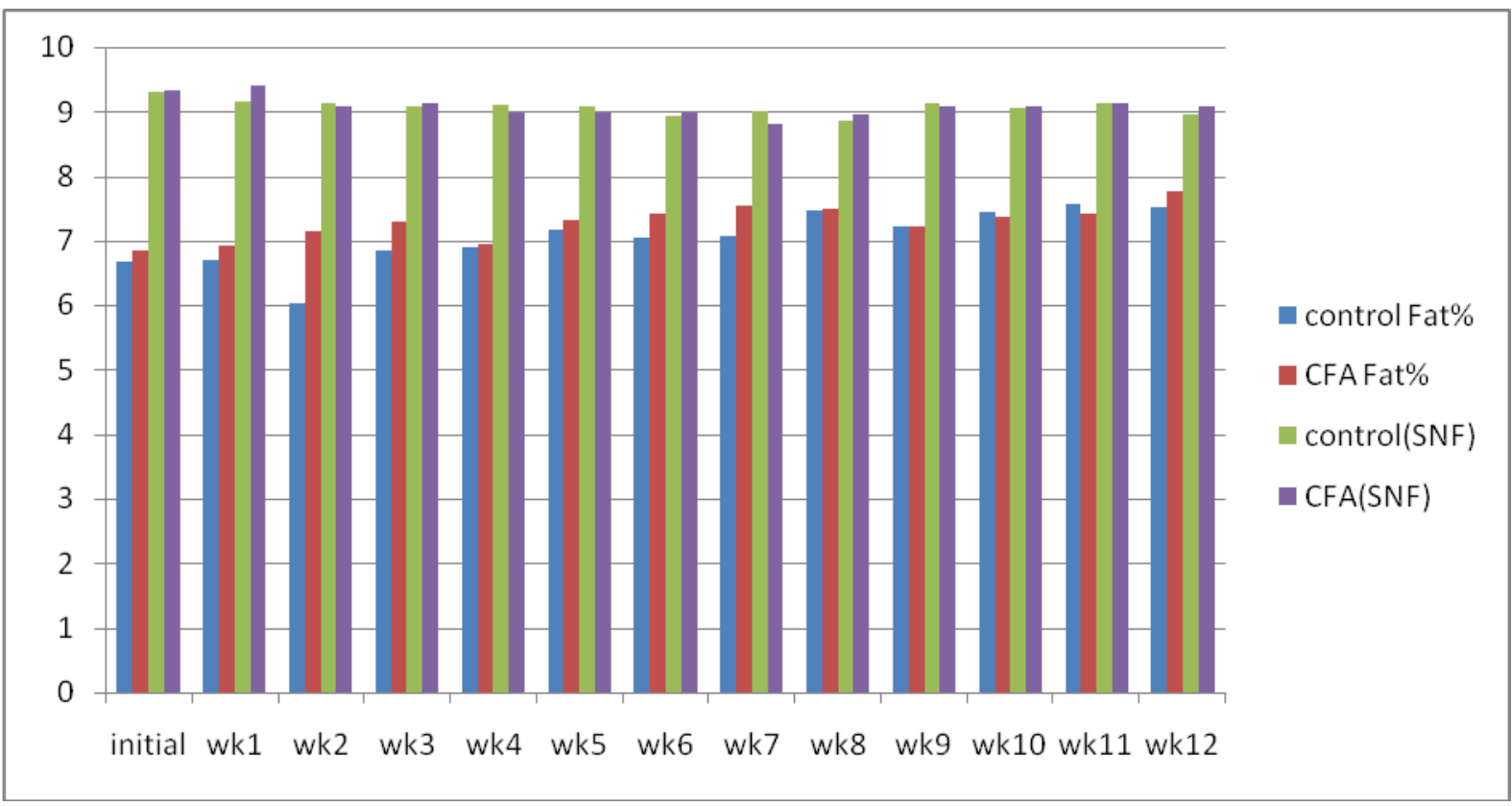

Milk fat $\%$ in treatment group in the end of trial was $7.76 \pm 0.78$ and that of control was $7.52 \pm 0.75$. Milk composition do not show significant variations in CFA fed buffaloes than control group. Figure 3 shows fluctuations in milk fat $\%$ and SNF\% in CFA group and control group.

Santos et al., (2010) observed that feeding of EO mixture containing eugenol, geranyl acetate and coriander oil as a major component of feed additive in dairy cows increased the total yield of milk fat or fat percentage in milk but has no effect on total milk production. Kholif et al., (2012) studied the effect of different plant essential oils (garlic, cinnamon and ginger oils) on the milk production in lactating Damascus goats, seven days after parturition. Results indicated that experimental additives, significantly increased milk yield, protein and solids not fat contents compared with the control, however fat percent and milk non protein nitrogen were decreased $(\mathrm{p}<0.05)$ by treatments compared to the control. Total solids and ash were not affected by the experimental additives. The experimental additives increased $(\mathrm{p}<0.05)$ unsaturated fatty acids in milk specially $\mathrm{C} 18: \ln 9 \mathrm{c}$ and conjugated linoleic acids (CLA).

Rennó et al., (2016) studied the effect of Cashew nut shell liquid (CNSL) and castor oil (CO), a commercial blend of functional oils (CNSL and CO) and monensin supplementation on milk yield and composition in multiparous Holstein cows. Both the feed additives supplementation reported to increase $(\mathrm{P}<0.01)$ total milk yield, protein and lactose yield than control group. Matloup et al., (2017) studied the effect of supplementation of monensin with coriander oil and salinomycin in early lactation Friesian cows and reported that coriander and salinomycin resulted in greater $(\mathrm{P}<0.05)$ daily outputs of milk, energy corrected milk, fat, and milk energy compared to control.

Vendramini et al., (2016) studied the effect of blend of essential oils, chitosan or monensin on nutrient utilization, blood profile, milk yield and milk composition of mid- to late-lactating and reported no significant changes in milk yield and composition among the treatments.

Composite feed additive have a positive effect 
on milk production in buffaloes. It do not affects the milk composition in treatment group but long term studies can be done in lactating animals to study fatty acid compositions in milk.

\section{References}

AOAC (2005). Official Methods of Analysis, 18th edition. Association of Official Analytical Chemists, Washington, DC.

Benchaar, C., Petit, H.V., Berthiaume, R., Whyte, T.D. and Chouinard, P.Y. (2006). Effects of addition of essential oils and monensin premix on digestion, ruminal fermentation, milk production and milk composition in dairy cows. Journal of Dairy Science, 89: 4352-4364.

Blanch, M., Carro, M.D., Ranilla, M.J., Viso, A., Vázquez-Ãnón, M. and Bach, A. (2016). Influence of a mixture of cinnamaldehyde and garlic oil on rumen fermentation, feeding behavior and performance of lactating dairy cows. Animal, Feed Science and Technology, 219: 313-323.

Dey, A., and De, P.S. (2014). Influence of condensed tannins from Ficus bengalensis leaves on feed utilization, milk production and antioxidant status of crossbred cows. Asian-Australasian Journal of Animal Sciences, 27(3): 342348.

FAO (2009). Food and Agriculture Organization of the United Nations. The State of Food and Agriculture. Livestock in the balance, Roma: FAO: 166.

ISI (1961) Methods of test for Dairy Industry (Part II) -Chemical Analysis of Milk. Bureau of Indian Standards, New Delhi.
Kholif, S.M., Morsy, T.A., Abdo, M.M., Matloup, O.H. and Abu El-Ella, A.A. (2012). Effect of Supplementing Lactating Goats Rations with Garlic, Cinnamon or Ginger Oils on Milk Yield, Milk Composition and Milk Fatty Acids Profile. Journal of Life Sciences, 4(1): 2734.

Matloup, O.H., Abd El Tawab, A.M., Hassan, A.A., Hadhouda, F.I., Khattab, M.S.A., Khalel, M.S., Sallam, S.M.A. and Kholif, A.E. (2017). Performance of lactating Friesian cows fed a diet supplemented with coriander oil: Feed intake, nutrient digestibility, ruminal fermentation, blood chemistry, and milk production. Animal Feed Science and Technology, 226: 8897.

Santos, M.B., Robinson, P.H., Williams, P. and Losa, R. (2010). Effects of addition of an essential oil complex to the diet of lactating dairy cows on whole tract digestion of nutrients and productive performance. Animal Feed Science and Technology, 157:64-71.

SPSS, (2009). Statistical Packages for Social Sciences, Version 16.0, SPSS Inc., SPSS. Statistical Package for the Social Sciences [Sotfware] Version 22.0. SPSS Inc.

Vendramini, T.H.A., Takiya, C.S., Silva, T.H., Zanferari, F., Rentas, M.F., Bertoni, J.C., Consentini, C.E.C., Gardinal, R., Acedd, T.S. and Rennó., F.P. (2016). Effects of a blend of essential oils, chitosan or monensin on nutrient intake and digestibility of lactating dairy cows. Animal Feed Science and Technology, 214: $12-21$.

\section{How to cite this article:}

Kiran and Avijit Dey. 2018. Effect of Composite Feed Additive on Fluctuations in Milk Production and Milk Composition in Lactating Murrah (Bubalus bubalis) Buffaloes. Int.J.Curr.Microbiol.App.Sci. 7(08): 182-186. doi: https://doi.org/10.20546/ijcmas.2018.708.024 